\author{
BEATA IWANICKA \\ Uniwersytet im. Adama Mickiewicza \\ w Poznaniu
}

\title{
BARIERY I PRZYKLADY WSPARCIA W PROCESIE EDUKACJI W ŚRODOWISKU OSÓB Z WADAMI SŁUCHU
}

\begin{abstract}
Iwanicka Beata, Bariery i przykłady wsparcia w procesie edukacji w środowisku osób $z$ wadami stuchu [Difficulties and Examples of Support in the Education Process in the Environment of People with Hearing Impairments]. Studia Edukacyjne nr 43, 2017, Poznań 2017, pp. 247-261. Adam Mickiewicz University Press. ISSN 1233-6688. DOI: 10.14746/se.2017.43.15
\end{abstract}

The article presents the problems of deaf and hard of hearing people in education. This topic is widely analyzed. The text describes the difficulties experienced by students at school, at various stages of learning, and the barriers experienced by deaf and hard of hearing students at higher education levels. In general, the hearing deficit entails various communication complications. The person with hearing impairment has a limited opportunity to have different experiences and what is most important in the text - hearing loss or deafness often makes it impossible to gain an optimal education. There are different methods of educating people from the non-hearing environment, depending on the degree of hearing impairment. Hearing impaired student often has difficulty understanding Polish, as it is not always their first language (their first language may be the Polish sign language). Hearing impaired students sometimes don't understand academic texts because they have weaker poorer vocabulary due to their communication dysfunction. Another issue is the social isolation of many people with hearing impairments which often have a dilemma which environment to integrate with - with hearing or hearing impaired? Teaching staff approaches such people in different ways. Stereotypes do not help in educational progress (for example, the assumption that such students communicate only in sign language). It is important to be aware of the types of hearing loss and the different types of hearing (each hearing impaired hears differently and needs an individual approach). Finally, the article discusses the issue of education of people with hearing impairment from the category of "space". Through "space" you can understand here the environment (school space, classes and associated architectural-acoustic barriers) as well as the language of the Deaf. The sign language is specifically designed for living space (some of the signatures must be shown in the specified movement and direction, depending on the intention of the sender).

Key words: deaf and hard of hearing people, types of hearing loss, polish sign language, support in the education process 


\section{Wstęp}

Przemiany zachodzące obecnie w szkolnictwie specjalnym polegają przede wszystkim na zmianie podejścia do ucznia z niepełnosprawnościami. Dotyczą one zwrócenia uwagi na jego indywidualne, zmienione przez dysfunkcje, potrzeby, a co za tym idzie - na podejmowanie działań w celu stworzenia mu jak najlepszych warunków do normalnego funkcjonowania w społeczeństwie ${ }^{1}$. Niniejszy artykuł pragnie ukazać problemy, z jakimi spotykają się osoby z uszkodzeniem słuchu w procesie edukacji na wszystkich szczeblach. Nie(do)słyszący są pozbawieni najważniejszego zmysłu pozwalającego na orientację $\mathrm{w}$ otaczającej rzeczywistości oraz mającego niezaprzeczalny wpływ na odniesienie sukcesu edukacyjnego. W Polsce osoby z niepełnosprawnościami mogą uczęszczać do wszystkich typów szkół, zależnie od ich indywidualnych potrzeb, możliwości rozwojowych oraz posiadanych predyspozycji. Obecnie rośnie popularność kształcenia w placówkach integracyjnych i ogólnodostępnych. Niestety, nie zawsze są one do tego przystosowane - czy poprzez przygotowanie infrastruktury architektonicznej, czy świadomej i przygotowanej do pracy z uczniami ze specjalnymi potrzebami edukacyjnymi kadry nauczycieli.

\section{Bariery w procesie edukacji uczniów nie(do)słyszących}

Słuch odgrywa ważną rolę w procesie edukacji, jako że jest ona zdominowana przez komunikację foniczną. Dlatego, na początku należy poruszyć problem specyfiki zaburzeń towarzyszących osobom z wadami słuchu, które znacząco wpływają na uczenie się. Typowe skutki jakie niesie ze sobą ta dysfunkcja przedstawił Daniel Ling, który zauważył, że podstawowym i pierwotnym efektem głuchoty jest powodowanie przez nią ograniczeń w zakresie nabywania i używania języka w jego aspekcie komunikacyjnym. Wtórne efekty są bardziej rozległe i związane przede wszystkim ze zubożoną komunikacją, która (1) ogranicza możliwość przeżywania różnorodnych doświadczeń; (2) opóźnia rozwój osobisty i społeczny oraz (3) nie pozwala na osiągnięcie optymalnego dla danej osoby wykształcenia. Trzeci efekt jest szczególnie widoczny w momencie, w którym wychowanek kończy edukację. Niskie osiągnięcia edukacyjne ograniczają bowiem możliwość znalezienia zatrudnienia, zmniejszają perspektywy zarobkowe i możliwości wyboru

1 A. Przybysz, Niepetnosprawni w systemie oświatowym UE, Dialog i Edukacja, 2005, 1(164), s. 11. 
spędzania czasu wolnego. Ograniczenia te mogą z kolei w sposób znaczący, w wielu sferach, obniżyć jakość życia osoby niesłyszącej².

Bogdan Szczepankowski twierdzi, że kształcenie osób niesłyszących jest możliwe jedynie $\mathrm{w}$ warunkach integracyjnych ${ }^{3}$. Podkreśla on, że problem ten należy rozpatrywać odrębnie dla dwóch grup: (1) osób z uszkodzonym słuchem, kształconych $\mathrm{w}$ systemie integracyjnym, dla których głównym środkiem porozumiewania się jest mowa ustna, a jej odbiór oparty na wzroku i słuchu; (2) osób niesłyszących, absolwentów szkół dla niesłyszących, dla których podstawowym środkiem komunikacji jest język migowy, ponieważ opanowanie struktur językowych polszczyzny oraz techniki dobrego mówienia i odczytywania mowy z ust jako wyłącznego środka porozumiewania się okazało się dla nich niemożliwe4. Rozróżnienie to jest na tyle istotne, że każda $\mathrm{z}$ tych grup stosuje $\mathrm{w}$ swoim przypadku inne techniki zdobywania wiedzy. Osoby słabosłyszące często mają możliwość wykorzystywania resztek słuchowych, co przy dobrych warunkach akustycznych (niestety, obecnie w polskiej szkole trudno je zapewnić) powoduje, że są w stanie odbierać przekazywaną wiedzę jak inni uczniowie. Ich zasób słownictwa jest znacznie bogatszy niż osób niesłyszących, przez co łatwiej im przyswoić wiedzę dostępną $\mathrm{w}$ formie pisanej.

Kolejne problemy odnoszą się do: ograniczeń związanych z pełnym zrozumieniem treści materiału na poziomie odbiorczym, czynnym uczestnictwem w zajęciach, zwłaszcza w dyskusjach na równi z osobami słyszącymi. Niemożliwe staje się również samodzielne prowadzenie notatek, gdyż nie jest wykonalne jednoczesne pisanie, połączone $\mathrm{z}$ patrzeniem na twarz rozmówcy (w przypadku umiejętności czytania z ust, co wymaga wysokiej koncentracji). Wielu autorów podkreśla również problemy uczniów nie(do)słyszących związane z umiejętnością czytania ze zrozumieniem. $\mathrm{Na}$ podstawie niektórych badań można stwierdzić, że osoby głuche z dysfunkcją słuchu, niezależnie od ich wieku, często mogą mieć problemy $\mathrm{z}$ rozwinięciem umiejętności płynnego czytania ze zrozumieniem $\mathrm{w}$ języku ojczystym ${ }^{5}$. Korzystanie z literatury naukowej jest zatem dla tych osób po-

${ }^{2}$ D. Ling, The effects of hearing impairment. Newsounds, Washington 1985, s. 2 za: E. Domagała-Zyśk (red.), Metoda fonogestów w Stanach Zjednoczonych i w Polsce. Wspomaganie rozwoju językowego dzieci i młodzieży z uszkodzonym stuchem, Lublin 2009, s. 34-35.

${ }^{3}$ B. Szczepankowski, Wyrównywanie szans osób niestyszących: optymalizacja komunikacji jezzykowej, Siedlce 1998, s. 237.

${ }^{4}$ B. Szczepankowski, Wybrane zagadnienia kształcenia na poziomie wyższym osób z uszkodzonym stuchem, Student niepełnosprawny. Szkice i rozprawy, 1997, 1, s. 40.

${ }^{5}$ R. Trybus, M. Karchmer, School achievement scores of hearing impaired children: National data on achievement status and growth patterns, American Annals of the Deaf, 1977, 122, s. 62-69. 
ważnym problemem. Niuanse akademickiej terminologii są często niezrozumiałe dla słyszących studentów, a co dopiero dla osób z dysfunkcją słuchu6. Jednym z głównych celów edukacji powinno być wykształcenie nie(do)słyszących na sprawnych i kompetentnych czytelników. Warto nadmienić, że w tym środowisku są osoby, które dzięki pracy logopedów, rodziców oraz własnym wysiłkom swoim poziomem słownictwa nie odbiegają od ich słyszących rówieśników. Czytanie często jest szansą dla niepełnosprawnych słuchowo, gdyż bywa jedynym sposobem uczenia się, które może być całkowicie pod ich kontrolą. To właśnie dzięki książkom i tekstom nie(do)słyszący mają możliwość zdobycia wiedzy, pomimo że są osobami, które nie mają możliwości odbierania fonicznie informacji przekazywanych na zajęciach.

Osoby z dysfunkcją słuchu powinny w miarę możliwości przygotować się do odbioru nowych treści dydaktycznych przed pojawieniem się na danych zajęciach. Wcześniejsza samodzielna praca znacząco ułatwia przyswajanie wiedzy bezpośrednio $\mathrm{w}$ trakcie zajęć. Jednak niezbędnym elementem do takiego przygotowania jest uprzednie dokładne określenie, jaki zakres zagadnień będzie obowiązywać $\mathrm{w}$ ramach danego przedmiotu przez prowadzącego nauczyciela. Należy podkreślić, że sam uczeń nie(do)słyszący nie zawsze uważnie śledzi tok zajęć, nie nadąża za tempem przekazu, co może wynikać zarówno z szybszego męczenia się, wynikającego z większego wysiłku skoncentrowanego na zachowaniu uwagi. Zazwyczaj niemożliwe jest też dostosowanie tempa zajęć do indywidualnych potrzeb osób z dysfunkcją słuchu, zważając również na fakt, że w grupie znajdują się także inne słyszące osoby, lepiej nadążające za wywodem nauczyciela. Nie bez znaczenia na zakłócenia $\mathrm{w}$ odbiorze informacji stanowi również zła akustyka pomieszczeń dydaktycznych.

Często barierą edukacyjną jest praca w grupie. Istotne wydaje się tutaj powiązanie możliwości osoby nie(do)słyszącego ze współpracą w większym gronie. Takie sytuacje mają miejsce, kiedy uczestnictwo w zajęciach warsztatowych wymaga rozumienia wielu komunikatów, a pracy w zespole towarzyszy konieczność prowadzenia rozmowy ze słyszącymi. Również szybkie tempo pracy $\mathrm{w}$ grupie $\mathrm{i}$ brak możliwości dokładnego przetłumaczenia omawianych treści z języka polskiego na język migowy stanowi kolejną przeszkodę dla takich uczniów ${ }^{7}$. Rówieśnicy, a często nawet nauczyciele nie

${ }^{6}$ B. Szczepankowski, Niestyszacy, głusi, głuchoniemi: wyrównywanie szans, Warszawa 1999, s. 242.

7 I. Jagoszewska, Aktualizacje w ksztatceniu niestyszacych studentów surdopedagogiki, [w:] Edukacja niestyszacych: publikacja pokonferencyjna, red. M. Kowalska, E. Twardowska, Łódź 2011, s. 55 . 
znają języka migowego, toteż jeśli osoba nie(do)słysząca posługuje się językiem fonicznym, jej mowa jest niewyraźna, przez co trudno ją zrozumieć. $\mathrm{Na}$ dalszym szczeblu edukacji dochodzą problemy z realizacją programu nauczania - taki uczeń często nie rozumie, co się dzieje na lekcji, nie wie, o czym mówi nauczyciel, w wyniku czego nie rozumie omawianego tematu. Równolegle towarzyszą temu niekiedy skomplikowane relacje rówieśnicze uczniowie słyszący, nie rozumiejąc osoby głuchej, odsuwają się od niej. Nie nawiązują się między nimi głębsze relacje, żyją właściwie obok siebie, co prowadzi często do poczucia osamotnienia, izolacji społecznej, a nawet do zaburzeń nerwicowych czy stanów depresyjnych ${ }^{8}$. Także trudny aspekt związany $\mathrm{z}$ aktywnym uczestnictwem $\mathrm{w}$ sektorze edukacji dla osób nie(do)słyszących stanowi proces adaptacji w środowisku oraz odpowiednie przygotowanie do testów i zaliczeń. Problemem jest również forma egzaminów maturalnych, nie zawsze dostosowanych do potrzeb osób nie(do)słyszących ${ }^{9}$.

Jako priorytet $\mathrm{w}$ oświacie i szkolnictwie wyższym warto rozważyć umożliwienie osobom z niepełnosprawnością słuchową jak najlepszego dostępu do edukacji poprzez likwidację przeszkód i utrudnień. Do najczęściej napotykanych barier można zaliczyć: psychologiczne, społeczne, prawne i architektoniczne.

Bariery psychologiczne stanowią trudności w zaakceptowaniu własnej sytuacji związanej z niepełnosprawnością, opóźniające podejmowanie procesu rehabilitacji i obniżające efekty edukacji. Istotnymi przeszkodami do pokonania, które bazują na wieloletnich uprzedzeniach, stereotypach i lękach skierowanych wobec osób z niepełnosprawnościami, są widoczne postawy nauczycieli oraz innych uczniów ${ }^{10}$. Trudności społeczne są natomiast powiązane z częstymi, negatywnymi reakcjami środowiska społecznego, w szczególności okazywanej niechęci, i obojętności, co może prowadzić do ograniczenia kontaktów, a w konsekwencji - do izolacji osób nie(do)słyszących.

Odnośnie barier prawnych, następną kwestią dotykającą wielu niepełnosprawnych jest brak posiadania orzeczenia o stopniu niepełnosprawności. Dotyczy to osób, które pomimo swoich schorzeń nie zgłaszają tego faktu do

8 K. Kochan, Studenci głusi i niedostyszacy na uczelniach wyższych, [w:] Globalno-lokalne wyzwania uczelni wyższych związane z niepetnosprawnościa, red. B.A. Orłowska, P. Prüfer, Gorzów Wielkopolski 2013, s. 109. Łódź 2016.

9 A. Wiśniewska, Egzaminy zewnętrzne a uczniowie z wadą stuchu - studium przypadku,

10 I. Cytlak, Studia wyższe a jakość życia osób niepetnosprawnych: studium porównawcze, Poznań 2009, s. 111. 
miejskich komisji i powiatowych zespołów ds. orzekania o niepełnosprawności, przez co tracą one możliwości otrzymania pomocy specjalnie im dedykowanej (indywidualna organizacja studiów, stypendium specjalne, programy wspierające itp.). Trudności tych nie można ominąć z powodu braku możliwości zastosowania istniejących przepisów do takich przypadków. Dopiero otrzymanie odpowiednich dokumentów orzekających o niepełnosprawności pozwala na korzystanie z dostępnych udogodnień.

\section{Wspomaganie procesu edukacji uczniów nie(do)słyszących}

W praktyce można wyróżnić dwa odmienne podejścia, jakie są stosowane przez nauczycieli względem osób nie(do)słyszących: (1) obligatoryjne kryteria umożliwiające ocenę nie(do)słyszących jako bardzo dobrych studentów; (2) obniżone progi wymagań ujawniające niskie osiągnięcia studentów nie(do)słyszących ${ }^{11}$.

Na drugie podejście nakładają się indywidualne przekonania nauczycieli, ich własne nastawienia i cele oraz dotychczasowa wiedza oraz doświadczenie o możliwościach i ograniczeniach osoby nie(do)słyszącej. Iwona Jagoszewska zauważa, że przejawem tego typu zachowań jest między innymi zgoda na preferencyjne egzekwowanie wiedzy od podopiecznych przez nauczycieli. Ze strony kadry dydaktycznej pojawiają się wówczas takie postawy, jak: wystawianie pozytywnej oceny za bierne asymilowanie wiedzy; tolerowanie biernego uczestnictwa w zajęciach oraz długotrwałych okresów braku uwagi; uprzywilejowanie w sytuacjach udzielania niepoprawnych odpowiedzi oraz akceptowanie niepoprawnej pod względem gramatycznym i stylistycznym wypowiedzi ${ }^{12}$.

Bogdan Szczepankowski wyróżnia trzy stereotypy spotykane wśród nauczycieli względem nie(do)słyszącego ucznia: (1) stereotyp ciężko pokrzywdzonej przez los kaleki, której nie należy stawiać wysokich wymagań, a raczej chronić i pozwalać spokojnie żyć; (2) stereotyp pełnosprawnego człowieka, który jedynie nie słyszy, więc należy go traktować jako zdrową osobę; (3) podejście do osoby nie(do)słyszącej, która będzie prawidłowo się rozwijać wtedy, gdy będzie się kładło nacisk w jej edukacji przede wszystkim na język migowy ${ }^{13}$.

\footnotetext{
${ }^{11}$ I. Jagoszewska, Aktualizacje w ksztatceniu niestyszacych studentów surdopedagogiki, s. 53.

12 Tamże.

${ }^{13}$ B. Szczepankowski, Niestyszący, głusi, głuchoniemi, s. 170.
} 
Umacnianiu pierwszego z wyżej wymienionych stereotypów (niepełnosprawnej i niesamodzielnej kaleki) sprzyja to, iż jeżeli nie(do)słyszący student nie utrzymuje wskazanego mu tempa pracy oraz nie mobilizuje się do wysiłku przy występujących trudnościach wynikających z komunikacji powstają braki w wiedzy, którą powinien posiadać na danym etapie edukacji. Uczelnia wymaga od tych studentów bardzo dobrej komunikacji; na podstawie własnej obserwacji Autorka niniejszego artykułu mogła dostrzec, że kadra akademicka wyróżnia dwa typy studentów z dysfunkcją słuchu. Pierwsza grupa to studenci chętnie uczestniczący w zajęciach, świetnie przygotowani na podstawie wcześniej opracowanych własnych notatek, zostają po zajęciach i korzystają z dyżurów kadry akademickiej w celach konsultacji. Przedstawiciele tej części społeczności nie(do)słyszących wykazują się sumiennością i konsekwencją w nauce. Natomiast drugą grupę stanowią studenci, którzy nie przygotowują się do zajęć, nie mają żadnych notatek, zaległości u nich są narastające, przez co zwiększa się liczba niezrozumiałych zagadnień. Niekiedy osoby te argumentują, że gdyby miały możliwość korzystania z naturalnego języka migowego albo lepszego wsparcia technicznego nie mieliby takich problemów ze zrozumieniem treści merytorycznej czy wygłaszanego wykładu.

Osoby z uszkodzonym narządem słuchu muszą dokonać niekiedy trudnego wyboru: czy zintegrować się z osobami słyszącymi czy może z osobami nie(do)słyszącymi? Podjęcie tej decyzji może być trudne i zależy od takich czynników, jak środowisko, w którym się wychowują, stopień opanowania mowy dźwiękowej, czy socjalizacja w danym środowisku.

Nie(do)słyszący niezależnie od sposobu jest przygotowany do funkcjonowania w społeczności osób słyszących, choć bardzo często znajduje się na marginesie. Nie należy on bowiem w pełni do społeczności osób słyszących, a jego specyficzne potrzeby niezbędne $\mathrm{w}$ jej funkcjonowaniu są dla reszty społeczeństwa niezrozumiałe. Przekłada się to na kontakty interpersonalne w okresie studiów, co wiąże się z problemami w nawiązaniu kontaktów $\mathrm{z}$ innymi słyszącymi studentami.

Wśród specjalnych potrzeb, jakie sygnalizują studenci nie(do)słyszący można wymienić: konsultacje indywidualne; kontakt poprzez SMS; kontakty interaktywne za pomocą Internetu: czatu, komunikatora Skype, poczty elektronicznej, strony internetowej; zapewnienie pomocy tłumacza języka migowego w czasie egzaminów i zaliczeń; terminy zaliczeń dostosowane do potrzeb studenta i tłumacza ${ }^{14}$.

${ }^{14}$ I. Jagoszewska, Aktualizacje w kształceniu niestyszących studentów surdopedagogiki, s. 57. 
Badania przeprowadzone przez Jarosława Bąbkę wśród studentów niepełnosprawnych pomogły wyróżnić istotne zmiany, które powodują zwiększenie dostępności uczelni wyższej. Propozycje te dotyczą: planowania zajęć (zmniejszenia przerw pomiędzy zajęciami, planowania zajęć $\mathrm{w}$ jednym budynku) ${ }^{15}$; organizacji toku studiowania (możliwość indywidualnego toku studiów, studiowania niektórych przedmiotów przez Internet, wyboru formy egzaminu, wydłużenia terminu zdawania egzaminów w uzasadnionych przypadkach); kwestii socjalno-usługowych (przyznawanie przystosowanych akademików z pomieszczeniami, z dzwonkiem i alarmem świetlnowibracyjnym, zwiększenia wysokości stypendium socjalnego, powołania komórki ds. niepełnosprawnych studentów, rozpowszechniania informacji na temat pomocy, z której korzystać mogą studenci, stworzenia im oferty rehabilitacyjnej) ${ }^{16}$.

\section{Typy ubytków słuchu i ich konsekwencje dla procesu edukacji}

Warto przybliżyć, na ile to możliwe, w jaki sposób słyszą osoby $\mathrm{z}$ różnymi uszkodzeniami słuchu. Jednakże, należy podkreślić, że przedstawione poniżej przykłady nie odzwierciedlają wyczerpująco procesu słyszenia i jego zaburzeń. Każdy przypadek osoby z nie(do)słuchem należy rozpatrywać indywidualnie. Osoby te mają różnoraką zdolność słyszenia, która zależy nie tylko od rodzaju uszkodzenia słuchu, ale również od wieku, w jakim dana osoba straciła słuch oraz pracy, jaki włożyła w rozwój mowy (praca z logopedą, rehabilitacja domowa, dopasowanie aparatu słuchowego) i innych czynników ${ }^{17}$.

Przedstawiona poniżej tabela prezentuje podział na stopień ubytku słuchu i jego konsekwencje dla rozumienia mowy oraz języka, jak również wyszczególnione specjalne potrzeby edukacyjne dla poszczególnych grup.

15 Choć dla niektórych studentów nie(do)słyszących skondensowanie zajęć w jednym dniu może powodować zmęczenie uniemożliwiające aktywne "słuchanie”, to dość istotna jest możliwość wyboru sali z dobrą akustyką.

${ }^{16}$ I. Cytlak, Studia wyższe a jakość życia osób niepetnosprawnych, s. 115.

17 B. Krystkowiak, Kształcenie studentów nie(do)styszących - problemy i postulaty, [w:] Student z niepetnosprawnościa w szkole wyższej, red. B. Tylewska-Nowak, W. Dykcik, Poznań 2013, s. 152. 
Tabela 1

Podział na stopień ubytku słuchu i jego konsekwencje dla rozumienia mowy oraz języka z wyszczególnieniem specjalnych potrzeb edukacyjnych

\begin{tabular}{|c|c|c|}
\hline Stopień ubytku słuchu & $\begin{array}{c}\text { Konsekwencje } \\
\text { dla rozumienia mowy } \\
\text { i języka }\end{array}$ & $\begin{array}{l}\text { Szczególne potrzeby } \\
\text { edukacyjne }\end{array}$ \\
\hline $\begin{array}{l}15-25 \mathrm{~dB} \\
\text { (granica normy) }\end{array}$ & $\begin{array}{l}\text { Trudności w rozumieniu } \\
\text { cichej mowy z większej } \\
\text { odległości, na ogół bez } \\
\text { problemów z artykulacją, } \\
\text { może być mniejszy zasób } \\
\text { słownictwa }\end{array}$ & $\begin{array}{l}\text { Korzystne miejsce w sali dla } \\
\text { obserwacji i odbioru mowy } \\
\text { (pierwsza ławka w rzędzie } \\
\text { pod oknem, bliżej okna). } \\
\text { Rozwijanie słownictwa }\end{array}$ \\
\hline $\begin{array}{l}30-45 \mathrm{~dB} \\
\text { (łagodny niedosłuch) }\end{array}$ & $\begin{array}{l}\text { Problemy ze słyszeniem } \\
\text { z odległości ponad } 1 \text { metra, } \\
\text { twarzą w twarz rozmowa } \\
\text { bez trudności. Podczas } \\
\text { lekcji umyka } 50 \% \text { dyskusji } \\
\text { (jeśli mówią cicho lub nie } \\
\text { widać twarzy), może mieć } \\
\text { trudności w artykulacji }\end{array}$ & $\begin{array}{l}\text { Korzystne miejsce w sali. } \\
\text { Używanie aparatu słuchowe- } \\
\text { go. Systematyczne zajęcia } \\
\text { w zakresie treningu słucho- } \\
\text { wego. Ćwiczenia odczytywa- } \\
\text { nia z ust. Regularne zajęcia } \\
\text { logopedyczne w celu rehabi- } \\
\text { litacji mowy. Niekiedy indy- } \\
\text { widualna pomoc pedago- } \\
\text { giczna w realizacji programu } \\
\text { nauczania }\end{array}$ \\
\hline $\begin{array}{l}50-75 \mathrm{~dB} \\
\text { (umiarkowany niedo- } \\
\text { słuch) }\end{array}$ & $\begin{array}{l}\text { Bez aparatu nie odbiera nic } \\
\text { z treści lekcji, rozumie gło- } \\
\text { śną mowę z odległości } 1 \\
\text { metra, mogą być trudności } \\
\text { z odbiorem i rozumieniem } \\
\text { innych dźwięków } \\
\text { z otoczenia, wadliwa arty- } \\
\text { kulacja }\end{array}$ & $\begin{array}{l}\text { jw. } \\
\text { Możliwość integracyjnego } \\
\text { kształcenia w zakresie wy- } \\
\text { branych przedmiotów }\end{array}$ \\
\hline $\begin{array}{l}80 \text { - } 95 \text { dB } \\
\text { (ciężki ubytek słuchu) }\end{array}$ & $\begin{array}{l}\text { Może słyszeć jedynie głośne } \\
\text { dźwięki z otoczenia, mowa } \\
\text { i język rozwiną się tylko } \\
\text { wówczas, kiedy była wcze- } \\
\text { sna diagnoza i rehabilitacja, } \\
\text { mowa nie zawsze zrozu- } \\
\text { miała, choć może brzmieć } \\
\text { prawie normalnie (np. rytm } \\
\text { mowy, cechy głosu) }\end{array}$ & $\begin{array}{l}\text { jw. } \\
\text { Codzienna pomoc pedago- } \\
\text { giczna w realizacji programu }\end{array}$ \\
\hline
\end{tabular}




\begin{tabular}{|l|l|l|}
\hline \multicolumn{1}{|c|}{ Stopień ubytku słuchu } & \multicolumn{1}{|c|}{$\begin{array}{c}\text { Konsekwencje } \\
\text { dla rozumienia mowy } \\
\text { i języka }\end{array}$} & $\begin{array}{c}\text { Szczególne potrzeby } \\
\text { edukacyjne }\end{array}$ \\
\hline $\begin{array}{l}95 \mathrm{~dB} \text { i więcej } \\
\text { (głęboki ubytek słuchu) }\end{array}$ & $\begin{array}{l}\text { Znikome szanse na sponta- } \\
\text { niczny rozwój mowy } \\
\text { i języka, niekiedy nie uży- } \\
\text { wają aparatu, bo mało sku- } \\
\text { teczny, mowa i język na } \\
\text { niskim poziomie rozwoju, } \\
\text { ograniczone możliwości } \\
\text { opanowania programu } \\
\text { szkolnego }\end{array}$ & $\begin{array}{l}\text { Konieczny język migowy } \\
\text { w porozumiewaniu się }\end{array}$ \\
\hline
\end{tabular}

Źródło: B. Wiśniewska, Dzieci z wada stuchu - specjalne potrzeby edukacyjne [w:] Tożsamość społecznokulturowa głuchych, red. E. Woźnicka, Łódź 2007, s. 122-123.

Osoba nie(do)słysząca kiedy posługuje się aparatem słuchowym bądź ma wszczepiony implant ślimakowy, słyszy dźwięk głosu ludzkiego, jednak nie jest w stanie rozróżnić sylab, co stanowi przyczynę jej zaburzonej umiejętności opanowania wzorców słów. Powoduje to, że niektóre słowa brzmią dla niej niemal identycznie i nie jest w stanie ich rozróżnić. Ponadto, może mieć problemy z kontrolą własnych wypowiedzi. U niektórych nie(do)słyszących ubożeje wówczas zasób słownictwa. Taki deficyt staje się przyczyną problemów ze zrozumieniem i tworzeniem mowy, równolegle może powodować trudności w czytaniu i pisaniu. Istotne jest zatem pytanie: jak osoby nie(do)słyszące mogą osiągnąć umiejętności wymagane na egzaminie maturalnym lub na uczelniach wyższych ${ }^{18}$ ?

Problemy tych osób praktycznie niczym się nie różnią zależnie od kraju ich pochodzenia. Jedynie można zaznaczyć, że w Polsce muszą one opanować znacznie trudniejszą gramatykę języka polskiego niż np. ich angielscy rówieśnicy. Na uwagę zasługuje też fakt, że w Polsce mało dostrzegalne są ich problemy i nie ma odpowiedniego, ogólnodostępnego systemu wsparcia. Problemy te powodują, że najmniej liczną grupą osób z niepełnosprawnościami podejmującą studia są właśnie osoby nie(do)słyszące.

Dokonując analizy wszystkich czynników składających się na proces słyszenia, można zauważyć, że jest on zależny od bardzo wielu elementów. Właśnie ta złożoność powoduje, że tak trudne jest sporządzenie jednoznacz-

${ }^{18}$ K. Krakowiak, Polskie fonogesty, [w:] Metoda fonogestów w Stanach Zjednoczonych i Polsce: wspomaganie rozwoju jezykowego dzieci $i$ młodzieży $z$ uszkodzonym stuchem, red. i przekł. E. Domagała-Zyśk, Lublin 2009, s. 52. 
nych wytycznych do komunikacji z osobami nie(do)słyszącymi. Co zastosujemy u jednej osoby, niekoniecznie będzie odnosiło się do drugiej. Często spotyka się opinie krytyczne odnośnie niektórych metod i zarzut wprowadzania bałaganu $\mathrm{w}$ rehabilitacji językowej osób z ubytkami słuchu. Jednak każdy nie(do)słyszący człowiek jest inny i może preferować odmienne metody komunikacji bądź edukacji, które powinny być maksymalnie zindywidualizowane. Taki zabieg indywidualizacji utrudnia przyjęcie jednej spójnej strategii w nauczaniu tej grupy osób. Każda metoda wsparcia jest dobra o ile przynosi efekty, nawet pomagając tylko jednej osobie.

\section{Przestrzeń języka migowego w edukacji ucznia nie(do)słyszącego}

Istotnym aspektem, jaki warto wziąć pod uwagę w procesie edukacji, jest przestrzeń, która może wspierać lub ograniczać nie(do)słyszącego ucznia. Można ją rozumieć tutaj dwojako: po pierwsze, jako środowisko nas otaczające, czyli przestrzeń szkoły, klasy oraz wiążące się z tym bariery architektoniczne. Po drugie, przestrzeń jako medium-nośnik służącą do komunikacji, która ma bardzo istotne znaczenie w posługiwaniu się chociażby Polskim Językiem Migowym. W systemie kształcenia proces edukacji polega na wzajemnej komunikacji. Jest ona tutaj rozumiana jako dźwięk, który swobodnie pokonuje przestrzeń. Kiedy jednak $w$ procesie tym bierze udział osoba $\mathrm{z}$ wadą słuchu, przestrzeń ta musi być pokonana poprzez usunięcie barier, w celu zapewnienia swobodnej, alternatywnej do języka fonicznego komunikacji.

Odnosząc się do pierwszego rozumienia tego terminu, wbrew stereotypom dotyczącym barier architektonicznych, dosięgają one nie tylko osób z niepełnosprawnością ruchową czy wzrokową, ale także między innymi $\mathrm{z}$ niepełnosprawnością słuchową, o czym wzmiankowano wcześniej w niniejszym artykule. Dobrym pomysłem byłoby dostosowanie budynków do ich ograniczeń, na przykład poprzez zainstalowanie specjalnych ekranów $\mathrm{z}$ bieżącymi informacjami odnośnie miejsca odbywających się zajęć w salach, świetlnego systemu alarmowego, dzwonków świetlnych w akademikach, tabliczek informacyjnych, a także odpowiedniej akustyki sali oraz wzbogacenie przestrzeni w sprzęt znacząco poprawiający jakość słyszenia. Najlepszym miejscem do edukacji i życia codziennego dla osób posługujących się Polskim Językiem Migowym jest przestronna przestrzeń, w której nie ma wielu ograniczeń komunikacyjnych tak, aby miganie między pomieszcze- 
niami było możliwe. Natomiast osoby preferujące foniczny przekaz lepiej funkcjonują w mniejszych i dobrze wygłuszonych pomieszczeniach (jeśli nie są wyposażone w system wspomagający słyszenie).

Rozwijając drugie znaczenie pojęcia „przestrzeni”, ważne jest zrozumienie ograniczonego dostępu do języka fonicznego u osób z wadami słuchu. Ta bariera może być kompensowana za pomocą innych systemów, jak język migowy czy gesty. Myśli, słowa migowe, zdania nabierają wyrazu dzięki układom dłoni, lokacjom, ruchom i sygnałom niemanualnym przekazywanym w przestrzeni. Za pomogą tego połączenia jest możliwa komunikacja ${ }^{19}$.

Istotnym elementem, nieobecnym w językach fonicznych, jest tzw. gramatyka twarzy. Służy ona do zadawania pytań ogólnych, typu "czy", na które możemy jedynie odpowiedzieć "tak" bądź "nie”. Tworzy się je poprzez dodanie funkcji niemanualnej. Również w pytaniach szczegółowych, gdzie pytajniki znajdują swoje miejsce na końcu zdania używa się tych funkcji, a także w negacji i potwierdzeniu oraz przy stopniowaniu. Kolejnym elementem, gdzie przestrzeń $w$ języku migowym jest niezbędna do tworzenia komunikatów są zaimki dzierżawcze np. "mój”, „twój”, , „jego”, „,jej”. Tworzy się te słowa poprzez użycie tego samego układu jednej ręki, ale nadaje $\mathrm{mu}$ znaczenie $\mathrm{w}$ momencie odpowiedniego ruchu $\mathrm{w}$ przestrzeni. Tak samo jest $\mathrm{z}$ określeniem stopnia pokrewieństwa, które zaznacza się przez określoną pozycję podmiotu w zdaniu ${ }^{20}$.

Jedną z funkcji, jaką pełni przestrzeń w językach migowych jest funkcja topograficzna. Polega ona na odtworzeniu mapy świata rzeczywistego. Stanowi prezentację obiektów w przestrzeni takimi jakimi są. Używając przykładu, jeśli chcielibyśmy przedstawić rozkład stanowisk w urzędzie bądź układ działów w sklepie, wówczas przedstawiamy ich położenie zgodne $\mathrm{z}$ ich rzeczywistym położeniem $\mathrm{w}$ relacji $\mathrm{z}$ innymi obiektami. Ta struktura gramatyczna osobom dopiero uczącym się języka migowego sprawia na początku wiele trudności. Zapominają, że należy wszystkie komunikaty odczytywać na zasadzie lustrzanego odbicia ${ }^{21}$.

Istotnym problemem dotyczącym podjęcia edukacji jest problem tzw. drugiego języka. Osoby nie(do)słyszące posługujące się Polskim Językiem Migowym (PJM), który ma swoją gramatykę odmienną od gramatyki języka polskiego, tak naprawdę odbierają go jako język obcy. Mimo że osoby nie(do)słyszące na co dzień „obcują" z językiem polskim, nie zawsze są

19 P. Romanowska, D. Rzeźniczak, M. Garncarek, Migaj migiem. Polski Język Migowy dla początkujących, Łódź 2011, s. 29.

20 Tamże, s. 18-29.

21 Tamże, s. 61. 
kompetentne w zakresie jego używania. W Polsce istnieje przekonanie, że osoby te powinny przystępować do egzaminów pisemnych. Jednakże, należy pamiętać, że język polski może być dla nich językiem obcym i mogą mieć problemy $\mathrm{z}$ przekazaniem swojej wiedzy $\mathrm{w}$ formie pisemnej. Niestety, z powodu braku powszechnego dostępu tłumacza języka migowego są one skazane na zaliczenia $\mathrm{w}$ takiej formie, co nie zawsze spotyka się ze zrozumieniem ze strony prowadzących zajęcia.

Inna sytuacja dotyczy osób niesłyszących, których macierzysty język stanowi Polski Język Migowy (PJM), a język polski jest ich drugim językiem (obcym). Jak podkreśla Szczepankowski, barierą dla tych osób biegle posługujących się PJM może być sam język migowy. Brak znaków migowych związanych z określoną dziedziną nauki może stać się przyczyną trudności $\mathrm{w}$ bezpośrednim tłumaczeniu specjalistycznych tekstów ${ }^{22}$.

Podstawowym warunkiem wszechstronnego rozwoju osoby nie(do)słyszącej jest osiągnięcie przez nią umiejętności posługiwania się językiem. Aby sprawnie się nim posługiwać, nie wystarczy słyszeć głos, ale należy mieć umiejętność rozumienia słów. Jak trafnie to ujął Robert Orin Cornett: „nie głos, ale słowo jest prawdziwym problemem głuchych"23.

\section{Podsumowanie}

Bez odpowiedniej wrażliwości ze strony kadry nauczycielskiej wysiłki surdopedagogów i pedagogów specjalnych nie odniosą większego rezultatu. Niezbędna jest tutaj podstawowa empatia społeczna, aby zrozumieć specyficzne i nie zawsze zrozumiałe dla innych trudności edukacyjne, z jakimi boryka się uczeń nie(do)słyszący. Potrzebne jest tu kompleksowe i możliwie zindywidualizowane podejście. Osoby z niepełnosprawnością słuchową są, pod pewnymi względami, społecznie najbardziej narażone na alienację $\mathrm{w}$ procesie edukacji. $\mathrm{W}$ dobie postulatów kształcenia inkluzywnego zasadne staje się dostrzeżenie problemu tych jednostek w szkole, na różnych szczeblach kształcenia. Im wcześniej uczeń uzyska pomoc i zostanie zauważony, tym lepiej dla jego osobniczego rozwoju. Niektóre deficyty poznawcze, a w szczególności umiejętności komunikacyjne i językowe niełatwo nadrobić na późniejszym etapie kształcenia.

Uczeń z niepełnosprawnością słuchową stanowi we współczesnym procesie edukacji wyzwanie. Jednakże, warto potraktować go nie tylko jako

22 B. Szczepankowski, Wyrównywanie szans osób niestyszących, s. 239.

${ }^{23}$ K. Krakowiak, Polskie fonogesty, s. 51. 
problem integracyjny w szkołach, ale także zwrócić uwagę, co może on zaoferować nauczycielom i rówieśnikom. Jeśli taki wychowanek spotka się ze zrozumieniem i odpowiednio dostosowanym wsparciem, odwdzięczy się swoim entuzjazmem i radością, że może przynajmniej w dużej części partycypować w swojej społeczności edukacyjnej. Pamiętajmy przede wszystkim, że szeroko rozumiany świat nauki i kultury oraz uniwersalnie rozumianych wartości duchowych ${ }^{24}$ powinien stać otworem dla każdego człowieka. Także i dla tego, który nie słyszy, ale inni, jeśli chcą, mogą jego usłyszeć.

\section{BIBLIOGRAFIA}

Cytlak I., Studia wyższe a jakość życia osób niepetnosprawnych: studium porównawcze, Wydawnictwo Naukowe UAM, Poznań 2009.

Domagała-Zyśk E. (red.), Metoda fonogestów w Stanach Zjednoczonych i w Polsce. Wspomaganie rozwoju językowego dzieci i młodzieży z uszkodzonym stuchem, Wydawnictwo KUL, Lublin 2009.

Jagoszewska I., Aktualizacje w kształceniu niestyszacych studentów surdopedagogiki, [w:] Edukacja niestyszacych: publikacja pokonferencyjna, red. M. Kowalska, E. Twardowska, Polski Związek Głuchych, Łódź 2011

Kochan K., Studenci głusi i niedostyszacy na uczelniach wyższych, [w:] Globalno-lokalne wyzwania uczelni wyższych związane z niepetnosprawnościa, red. B.A. Orłowska, P. Prüfer, Wydawnictwo Naukowe PWSZ w Gorzowie Wielkopolskim, Gorzów Wielkopolski 2013.

Krakowiak K., O wsparcie studentów niestyszących w społeczności akademickiej Katolickiego Uniwersytetu Lubelskiego, Wydawnictwo KUL, Lublin 2003.

Krakowiak K., Polskie fonogesty, [w:] Metoda fonogestów w Stanach Zjednoczonych i Polsce: wspomaganie rozwoju językowego dzieci i młodzieży z uszkodzonym stuchem, red. i przekł. E. Domagała-Zyśk, Wydawnictwo KUL, Lublin 2009.

Krystkowiak B., Ksztatcenie studentów nie(do)styszących - problemy i postulaty, [w:] Student z niepetnosprawnościa w szkole wyższej, red. B. Tylewska-Nowak, W. Dykcik, Wydawnictwo Naukowe UAM, Poznań 2013.

Ling D., The effects of hearing impairment. Newsounds, Alexander Graham Bell Association for the Deaf, Washington 1985.

Przybysz A., Niepetnosprawni w systemie oświatowym UE, Dialog i Edukacja, 2005, 1(164).

Romanowska P., Rzeźniczak D., Garncarek M., Migaj migiem. Polski Jezzyk Migowy dla początkujących, Studio Koloru, Łódź 2011.

Szczepankowski B., Wybrane zagadnienia kształcenia na poziomie wyższym osób z uszkodzonym stuchem, Student niepełnosprawny. Szkice i Rozprawy, 1997, 1.

Szczepankowski B., Wyrównywanie szans osób niestyszących: optymalizacja komunikacji językowej, Wydawnictwo Uczelniane WSRP, Siedlce 1998.

${ }^{24} \mathrm{~K}$. Krakowiak, O wsparcie studentów niestyszących w społeczności akademickiej Katolickiego Uniwersytetu Lubelskiego, Lublin 2003, s. 5. 
Szczepankowski B., Niestyszacy, głusi, głuchoniemi: wyrównywanie szans, Wydawnictwa Szkolne i Pedagogiczne, Warszawa 1999.

Trybus R., Karchmer M., School achievement scores of hearing impaired children: National data on achievement status and growth patterns, American Annals of the Deaf, 1977, 122.

Wiśniewska A., Egzaminy zewnętrzne a uczniowie z wada stuchu - studium przypadku, Polski Związek Głuchych, Łódź 2016.

Wiśniewska B., Dzieci z wadą stuchu - specjalne potrzeby edukacyjne [w:] Tożsamość społecznokulturowa głuchych, red. E. Woźnicka, Polski Związek Głuchych, Łódź 2007. 